\title{
NOTE
}

\section{Molecular detection of the parasitic dinoflagellate Hematodinium perezi from blue crabs Callinectes sapidus in Louisiana, USA}

\author{
Timothy J. Sullivan ${ }^{1, *}$, Carey G. Gelpi ${ }^{2}$, Joseph E. Neigel ${ }^{1}$ \\ ${ }^{1}$ Department of Biology, University of Louisiana at Lafayette, Lafayette, Louisiana 70503, USA \\ ${ }^{2}$ Department of Environmental Sciences, Louisiana State University, Baton Rouge, Louisiana 70803, USA
}

\begin{abstract}
The dinoflagellate Hematodinium perezi is a prolific pathogen of the blue crab Callinectes sapidus along the Atlantic and Gulf of Mexico coasts of North America. High prevalence, sometimes approaching $100 \%$, and outbreaks with high mortality are associated with higher salinities. H. perezi has not been reported previously in blue crabs from Louisiana, USA, where salinities in coastal habitats are generally below the parasite's favorable range. However, the possibility that $H$. perezi infects blue crabs in higher salinity habitats offshore has not been investigated. A PCR-based test for $H$. perezi was used to screen blue crabs collected from both high and low salinity areas. These included juvenile and adult crabs from inshore marshes where salinities are relatively low and from higher salinity offshore shoals that are spawning sites for females. $H$. perezi was detected in blue crabs from offshore shoals (prevalence $=5.6 \%$ ) but not in juvenile or adult crabs from inshore habitats. Megalopae (post-larvae) were also collected from inshore locations. Although megalopae settle inshore where salinities are relatively low, the megalopal stage is preceded by a planktonic phase in higher salinity offshore waters. We detected $H$. perezi in $11.2 \%$ of settling megalopae tested. Although the prevalence of $H$. perezi was relatively low within our samples, if spawning females and megalopae are especially vulnerable, the impact on the population could be compounded. This is the first report of $H$. perezi from blue crabs in Louisiana and demonstrates the importance of examining all life stages in determining the prevalence of a harmful parasite.
\end{abstract}

KEY WORDS: Blue crab - Callinectes $\cdot$ Louisiana $\cdot$ Hematodinium $\cdot$ Dinoflagellate $\cdot$ Pathogen · Gulf of Mexico

Resale or republication not permitted without written consent of the publisher

\section{INTRODUCTION}

The dinoflagellate Hematodinium perezi is a virulent parasite of the blue crab Callinectes sapidus in North America (Shields \& Overstreet 2007), where the prevalence of infection is often as high as $30 \%$ and can approach $100 \%$. The mortality rate for infected crabs is also high: a study with captive individuals found $87 \%$ mortality after $40 \mathrm{~d}$ (Shields \& Squyars
2000). Not surprisingly, outbreaks of $H$. perezi are considered to be a major factor in regional declines of blue crab fisheries (Lee \& Frischer 2004). Symptoms of infection consist of lethargy and changes in hemolymph, including a decline in the number of hemocytes, reduced clotting ability, and discoloration (Shields \& Squyars 2000, Shields \& Overstreet 2007).

Surveys of infection by $H$. perezi in blue crabs typically report the prevalence of infection (percent- 
age of infected individuals) and occasionally the average intensity of infection (percentage of cells in the hemolymph that are parasites). Both prevalence and intensity vary seasonally and are correlated with salinity and temperature, although there is regional variation in these relationships (Messick \& Shields 2000, Gandy et al. 2015). Infection has been observed less frequently in waters with salinities below 11 ppt (Messick \& Shields 2000), while severe outbreaks are often associated with high salinities following droughts (Lee \& Frischer 2004, Parmenter et al. 2013, Gandy et al. 2015). In all of the previous surveys for $H$. perezi that included blue crabs from Louisiana, USA, none detected the pathogen in Louisiana (Messick \& Shields 2000, Pagenkopp Lohan et al. 2013, Rogers et al. 2015a,b) although infected crabs have been reported from the Gulf coasts of Texas, Florida and Mississippi, USA (Newman \& Johnson 1975, Messick \& Shields 2000, Shields \& Overstreet 2007, Gandy et al. 2015). The relatively low salinities of Louisiana's inshore waters, combined with limited sampling from higher salinity offshore habitats could explain the apparent absence of $H$. perezi in Louisiana. However, critical stages of the blue crab's life cycle take place offshore, where salinities tend to be higher. Female blue crabs migrate seaward to spawn because larvae require higher salinities for development (Sandoz \& Rogers 1944). Larvae remain offshore for 4-6 wk before they metamorphose to megalopae and begin to migrate inshore where they settle. Thus, even if $H$. perezi does not infect blue crabs in Louisiana's low salinity habitats, it could have significant impacts on reproductive females and larvae in offshore habitats. In the only study that we are aware of in which decapod larvae were tested for the presence of Hematodinium, i.e. Hamilton et

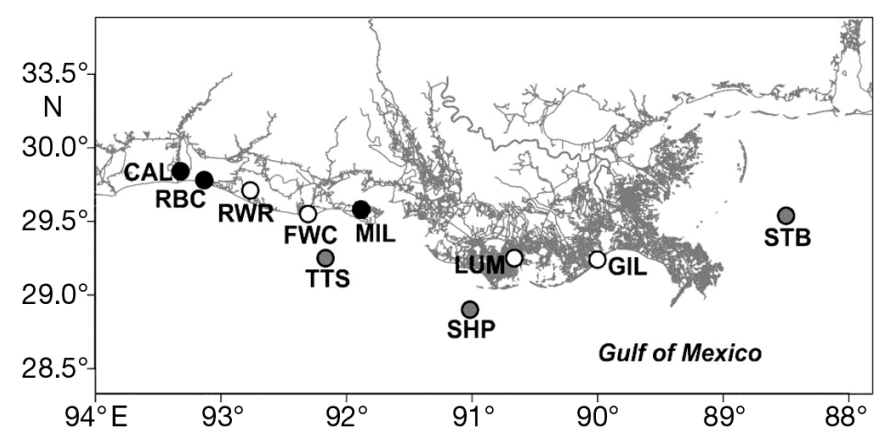

Fig.1. Sampling locations in Louisiana, USA, for coastal adult/juvenile blue crabs $(\bullet)$, coastal adult/juvenile blue crabs and megalopae (O), and offshore adult/juvenile blue crabs (๑) evaluated for the presence of Hematodinium perezi. See Table 1 for definition of abbreviations al. (2011), prevalence of $\sim 12-15 \%$ was reported throughout the summer for the larvae of both langoustines Nephrops norvegicus and unidentified crab species from the Clyde Sea in Scotland.

The present study investigates the possibility that $H$. perezi occurs in blue crabs in Louisiana but mainly in offshore habitats with higher salinities. We detected DNA of $H$. perezi in tissues of juvenile and adult crabs from offshore shoals as well as in megalopae settling in low salinity marshes. To our knowledge, these are the first reports of the presence of $H$. perezi from blue crabs in Louisiana.

\section{MATERIALS AND METHODS}

\section{Sample collection}

Blue crabs were collected during August 2014 in bottom trawls from 3 offshore shoal locations: St. Bernard Shoals, Ship Shoal, and the Tiger-Trinity Shoals Complex (Fig. 1). Trawl transects consisted of 30 min tows with a $7.3 \mathrm{~m}$ net pulled at $\sim 3$ knots. Size (carapace width from point to point) and weight were measured for each crab, and tissues (muscle, hepatopancreas, and ovary) were removed and freezedried. Crabs were collected from inshore habitats throughout the summer of 2014 with crab pots and by handline fishing at 7 coastal locations: Grand Isle, LUMCON, Marsh Island, Freshwater City, Rockefeller Wildlife Refuge, Rutherford Beach Culvert, and Lake Calcasieu (Fig. 1). For these crabs, $1 \mathrm{ml}$ of hemolymph was drained from the cardiac sinus with $100 \mu \mathrm{l}$ of sterile Soderhall and Smith's formulation added as an anticoagulant; the second walking leg on the right side was removed with forceps, and both samples were preserved in pre-chilled $95 \%$ ethanol at $4^{\circ} \mathrm{C}$. Settling megalopae were collected from 4 locations: Grand Isle, LUMCON, Freshwater City, and Rockefeller Wildlife Refuge (Fig. 1) in 2010, 2013, 2014, and 2015. At each location, 5 hog-hair collectors were deployed for $\sim 24 \mathrm{~h}$, after which these passive collectors were rinsed with ambient seawater. In addition, a $253 \mu \mathrm{m}$ plankton net (Wildco) was towed between 3 and 5 times over a total distance of $\sim 200 \mathrm{~m}$. Both types of samples were washed on a $200 \mu \mathrm{m}$ filter with ambient seawater, and all Callinectes sapidus megalopae were individually removed while still alive. The megalopae were then washed a second time with ambient seawater before being preserved whole in pre-chilled $95 \%$ ethanol at $4{ }^{\circ} \mathrm{C}$. Spot measurements of salinity and water temperature were taken at the time of each collection. 


\section{DNA extraction and detection of Hematodinium perezi DNA}

DNA initially was extracted from $\sim 2 \mathrm{mg}$ of freezedried muscle tissue, $\sim 200 \mu$ of preserved hemolymph, or from whole ethanol-preserved megalopae using NucleoSpin ${ }^{\circledR} 96$ Tissue Kits (Machery-Nagel) with an epMotion 5075 TMX liquid handling workstation (Eppendorf) following the manufacturer's protocol. The presence of DNA of $H$. perezi was detected by PCR amplification of a portion of the 18s ribosomal RNA gene using the primers Hemat-F-18S and Hemat-R18S developed by Friedman et al. (2009). For samples in which DNA of $H$. perezi was detected, DNA was subsequently extracted from hepatopancreas, ovary and, where available, egg-mass tissue using the same protocol. DNA concentrations were determined with a Nanodrop spectrophotometer (Thermo Scientific). PCR reactions were in $15 \mu \mathrm{l}$ with $1 \times$ AmpliTaq Gold ${ }^{\circledR}$ PCR Buffer (Applied Biosystems), $2.5 \mathrm{mM} \mathrm{MgCl}_{2}$, $(1 \mathrm{mM}) \mathrm{dNTPs},(1.2 \mu \mathrm{M})$ of each forward and reverse primer, 0.6 units of AmpliTaq ${ }^{\circledR}$ Gold (Applied Biosystems), $20 \mathrm{ng}$ of DNA, and Milli-Q ${ }^{\circledR}$ water. PCR conditions were as follows: $95^{\circ} \mathrm{C}$ for $5 \mathrm{~min}$, then 40 cycles of $96^{\circ} \mathrm{C}$ for $15 \mathrm{~s}, 56^{\circ} \mathrm{C}$ for $30 \mathrm{~s}, 72^{\circ} \mathrm{C}$ for $45 \mathrm{~s}$, and lastly $72^{\circ} \mathrm{C}$ for $10 \mathrm{~min}$. Positive and negative controls were included in all reactions. PCR products were electrophoresed on $2 \%$ agarose gels with $0.05 \%$ ethidium bromide and visualized on a Molecular Imager ${ }^{\circledR}$ Gel Doc TM XR system (Bio Rad).

\section{RESULTS}

Among the 54 blue crabs collected from offshore shoals in August 2014, DNA of Hematodinium perezi was detected in 3 , an overall prevalence of $5.6 \%$ (Table 1 ). All 3 were adult females (1 ovigerous) from St. Bernard Shoals, with point-to-point carapace widths ranging from 130 to $157 \mathrm{~mm}$. In each of these crabs, the DNA of $H$. perezi was detected in muscle and hepatopancreas tissues but not in ovary tissues or in the eggs of the ovigerous female. The PCR prevalence of $H$. perezi for crabs from St. Bernard Shoals $(20 \%)$ was significantly different from the zero prevalence for crabs from Ship Shoal and the Tiger-Trinity Shoals Complex $(\mathrm{p}=0.04$; 2-tailed Fisher's exact test; Table 1). DNA of $H$. perezi was not detected among the 262 juvenile and adult blue crabs collected from coastal marsh locations (Table 1). Prevalence of $H$. perezi DNA from crabs at the 7 coastal locations was significantly different than for crabs from the 3 offshore locations $(p=0.0047 ; 2$-tailed Fisher's exact test). Among the 582 settling megalopae, DNA of $H$. perezi was detected in $65(11.2 \%)$, with prevalence among individual collections ranging from 0 to $35 \%$ (Table 2). Prevalence in megalopae was higher in 2014 than 2010, 2013, or $2015\left(\chi^{2}=\right.$ 26.734, df $=3, \mathrm{p}<0.001$; Table 2), and higher in collections from Grand Isle than from other locations $\left(\chi^{2}=13.211, \mathrm{df}=3, \mathrm{p}=0.004\right.$; Table 2).

Table 1. Summary information for adult/juvenile blue crabs collected from the 7 coastal and 3 offshore shoaling areas in Louisiana, USA, including location, date of collection in 2014, latitude (Lat.), longitude (Long.), salinity, temperature, size range, sample size $(\mathrm{N})$, number positive $\left(\mathrm{N}_{\mathrm{P}}\right)$, and prevalence (Prev.)

\begin{tabular}{|c|c|c|c|c|c|c|c|c|c|}
\hline Location & $\begin{array}{l}\text { Date } \\
(\mathrm{mo} / \mathrm{d})\end{array}$ & $\begin{array}{l}\text { Lat. } \\
\left({ }^{\circ} \mathrm{N}\right)\end{array}$ & $\begin{array}{l}\text { Long. } \\
\left({ }^{\circ} \mathrm{E}\right)\end{array}$ & $\begin{array}{l}\text { Salinity } \\
\text { (ppt) }\end{array}$ & $\begin{array}{l}\text { Temp. } \\
\left({ }^{\circ} \mathrm{C}\right)\end{array}$ & $\begin{array}{l}\text { Size range } \\
(\mathrm{mm})\end{array}$ & $\mathrm{N}$ & $\mathrm{N}_{\mathrm{P}}$ & $\begin{array}{c}\text { Prev. } \\
(\%)\end{array}$ \\
\hline \multicolumn{10}{|l|}{ Coastal } \\
\hline Grand Isle (GIL) & $8 / 1$ & 29.24 & 90.00 & 22 & 30 & $115-170$ & 19 & 0 & 0 \\
\hline LUMCON (LUM) & $7 / 18$ & 29.25 & 90.66 & 7 & 28 & $106-180$ & 32 & 0 & 0 \\
\hline Marsh Island (MIL) & $7 / 16$ & 29.58 & 91.88 & 15 & 29 & $110-183$ & 33 & 0 & 0 \\
\hline $\begin{array}{l}\text { Freshwater City } \\
\text { (FWC) }\end{array}$ & $\begin{array}{c}\text { 6/16, 6/30 } \\
7 / 29 \& 8 / 12\end{array}$ & 29.55 & 92.31 & 6.3 & 28.5 & $63-200$ & 57 & 0 & 0 \\
\hline $\begin{array}{l}\text { Rockefeller Wildlife } \\
\text { Refuge (RWR) }\end{array}$ & $\begin{array}{l}6 / 16,6 / 30 \\
8 / 7, \& 8 / 12\end{array}$ & 29.71 & 92.77 & 7 & 29.7 & $98-175$ & 38 & 0 & 0 \\
\hline $\begin{array}{l}\text { Rutherford Beach } \\
\text { Culvert (RBC) }\end{array}$ & $\begin{array}{c}6 / 11,6 / 30 \& \\
8 / 7\end{array}$ & 29.78 & 93.13 & 10 & 30 & $50-172$ & 45 & 0 & 0 \\
\hline Lake Calcasieu (CAL) & $6 / 10,7 / 8$ & 29.84 & 93.32 & 15 & 28 & 88-182 & 38 & 0 & 0 \\
\hline Coastal total & - & - & - & - & - & $50-200$ & 262 & 0 & 0 \\
\hline \multicolumn{10}{|l|}{ Offshore } \\
\hline St. Bernard (STB) & $8 / 18$ & 29.54 & 88.11 & 36 & 24.1 & $130-174$ & 15 & 3 & 20 \\
\hline Ship (SHP) & $8 / 20$ & 28.90 & 91.02 & 29.6 & 30.2 & $162-169$ & 2 & 0 & 0 \\
\hline $\begin{array}{l}\text { Tiger-Trinity Shoals } \\
\text { Complex (TTS) }\end{array}$ & $8 / 21$ & 29.25 & 92.17 & 30.6 & 29.6 & $86-179$ & 37 & 0 & 0 \\
\hline Offshore total & - & - & - & - & - & $86-179$ & 54 & 3 & 5.6 \\
\hline
\end{tabular}


Table 2. Summary information for blue crab megalopae including latitude (Lat.), longitude (Long.), date of collection, salinity, temperature, sample size $(\mathrm{N})$, number positive $\left(\mathrm{N}_{\mathrm{P}}\right)$, and prevalence (Prev.). See Table 1 for definition of abbreviations

\begin{tabular}{|c|c|c|c|c|c|c|c|c|}
\hline Location & $\begin{array}{l}\text { Lat. } \\
\left({ }^{\circ} \mathrm{N}\right)\end{array}$ & $\begin{array}{l}\text { Long. } \\
\left({ }^{\circ} \mathrm{E}\right)\end{array}$ & $\begin{array}{c}\text { Date } \\
\text { (mo/d/yr) }\end{array}$ & $\begin{array}{l}\text { Salinity } \\
\text { (ppt) }\end{array}$ & $\begin{array}{c}\text { Temp. } \\
\left({ }^{\circ} \mathrm{C}\right)\end{array}$ & $\mathrm{N}$ & $\mathrm{N}_{\mathrm{P}}$ & $\begin{array}{r}\text { Prev } \\
(\%)\end{array}$ \\
\hline GIL & 29.24 & 90.00 & $\begin{array}{c}\text { 7/31/2010 } \\
8 / 31 / 2013 \\
8 / 1 / 2014 \\
8 / 18 / 2015 \\
\text { Total }\end{array}$ & $\begin{array}{c}12 \\
18 \\
22 \\
12 \\
-\end{array}$ & $\begin{array}{c}30 \\
32 \\
29.5 \\
30.5 \\
-\end{array}$ & $\begin{array}{c}35 \\
38 \\
43 \\
40 \\
156\end{array}$ & $\begin{array}{c}8 \\
3 \\
15 \\
2 \\
28\end{array}$ & $\begin{array}{c}23 \\
8 \\
35 \\
5 \\
18\end{array}$ \\
\hline LUM & 29.25 & 90.66 & $\begin{array}{c}8 / 29 / 2010 \\
8 / 21 / 2013 \\
7 / 18 / 2014 \\
8 / 16 / 2015 \\
\text { Total }\end{array}$ & $\begin{array}{c}4 \\
18 \\
7 \\
10 \\
-\end{array}$ & $\begin{array}{c}33 \\
30.5 \\
28.5 \\
33.5 \\
-\end{array}$ & $\begin{array}{c}36 \\
39 \\
37 \\
40 \\
152\end{array}$ & $\begin{array}{l}1 \\
4 \\
3 \\
0 \\
8\end{array}$ & $\begin{array}{c}3 \\
10 \\
8 \\
0 \\
5\end{array}$ \\
\hline FWC & 29.55 & 92.31 & $\begin{array}{c}8 / 1 / 2010 \\
8 / 25 / 2013 \\
8 / 12 / 2014 \\
8 / 11 / 2015 \\
\text { Total }\end{array}$ & $\begin{array}{l}20 \\
22 \\
10 \\
19 \\
-\end{array}$ & $\begin{array}{c}32 \\
34 \\
29 \\
31.5 \\
-\end{array}$ & $\begin{array}{c}36 \\
45 \\
39 \\
32 \\
152\end{array}$ & $\begin{array}{c}5 \\
1 \\
11 \\
1 \\
18\end{array}$ & $\begin{array}{c}14 \\
2 \\
28 \\
3 \\
12\end{array}$ \\
\hline RWR & 29.71 & 92.77 & $\begin{array}{c}8 / 9 / 2010 \\
8 / 25 / 2013 \\
8 / 12 / 2014 \\
8 / 11 / 2015 \\
\text { Total }\end{array}$ & $\begin{array}{c}17 \\
22 \\
0 \\
16 \\
-\end{array}$ & $\begin{array}{c}32 \\
34 \\
29 \\
32 \\
-\end{array}$ & $\begin{array}{c}36 \\
13 \\
38 \\
35 \\
122\end{array}$ & $\begin{array}{c}4 \\
0 \\
6 \\
1 \\
11\end{array}$ & $\begin{array}{c}11 \\
0 \\
16 \\
3 \\
9\end{array}$ \\
\hline $\begin{array}{l}\text { Louisiana } \\
\text { total }\end{array}$ & - & - & - & - & - & 582 & 65 & 11 \\
\hline
\end{tabular}

\section{DISCUSSION}

The most significant finding of this study is evidence that the parasitic dinoflagellate Hematodinium perezi occurs in blue crabs in Louisiana, as it does elsewhere along the Gulf of Mexico and Atlantic coasts of North America. To our knowledge these are the first reports of $H$. perezi in blue crabs from Louisiana. Our findings agreed with those of previous studies that did not detect this pathogen in blue crabs from Louisiana's coastal marshes. $H$. perezi appears to require salinities above $11 \mathrm{ppt}$ (Messick \& Shields 2000, Shields \& Overstreet 2007, Coffey et al. 2012); salinities in the coastal marshes of Louisiana are often below 11 ppt (Boesch et al. 1994) but generally higher offshore (Brown 2015). The distribution of infected adults is consistent with a negative effect of low salinities on $H$. perezi in Louisiana's marshes that does not fully extend to higher salinity offshore habitats. Alternatively, the DNA-positive females that we collected from St. Bernard Shoals in Louisiana could have been infected on the coast of Mississippi, where salinities are higher, and subsequently migrated to St. Bernard Shoals. The migration of blue crabs in the Gulf of Mexico could thus be important in the spread of $H$. perezi. Although infected megalopae were collected in lower salinity marshes, they would have recently encountered higher salinities during their larval phase. A potentially confounding factor in our study is collection method. Crabs were collected from offshore shoals by trawls but in baited traps from marshes. Traps could be less effective than trawls in collecting crabs that have become lethargic as the result of infection by $H$. perezi.

The overall prevalence of $H$. perezi among blue crabs sampled from the Gulf coast of Louisiana was low in comparison to values reported for many other locations. For instance, Gandy et al. (2015) reported prevalence of $H$. perezi in Jacksonville and Panama City, Florida, reached 63 and $68 \%$, respectively, during winter. Messick \& Shields (2000) found a cyclic pattern in prevalence from 1992 to 1997 in blue crabs from the lower Chesapeake Bay, with $~ 90 \%$ infected in late-fall peaks. However, it should not be concluded that $H$. perezi has little impact on blue crabs in Louisiana. Apart from the limited sampling (restricted to summer) on which this report is based, the prevalence of $H$. perezi must be considered in relation to other factors. The prevalence detected is the fraction of individuals that have encountered $H$. perezi but have not died. If the morality rate is high and death occurs quickly, prevalence represents only a small fraction of all those that may become infected and die. In captive crabs, $H$. perezi kills the majority of infected individuals within 6 wk (Shields \& Squyars 2000, Shields et al. 2015). Furthermore, high rates of infection for females spawning on offshore shoals and early life stages prior to settlement could have disproportionately large demographic impacts. Gelpi et al. (2009) showed that offshore spawning female crabs have the potential to spawn 7 times in a spawning season with an average of 2.5 million larvae released per spawn.

Blue crabs support a fishery in Louisiana that accounts for $\sim 80 \%$ of hard crab production in the Gulf of Mexico, totaling 43 million US\$ $\mathrm{yr}^{-1}$ (Perry \& VanderKooy 2015). Our findings suggest that infection by $H$. perezi should be a concern for the management of the blue crab fishery in Louisiana and should also be recognized as a factor that could be 
amplified by climate change and other anthropogenic disturbances. Ongoing and planned projects intended to preserve and restore Louisiana's coastline make use of large-scale hydrological diversions and sediment mining from offshore shoals (Stone et al. 2004, Moore et al. 2014). Reduction of the shoals, along with the encroachment of hypoxic zones (Bianchi et al. 2010), will reduce critical spawning areas for female blue crabs (Gelpi et al. 2009, 2013, Condrey \& Gelpi 2010) and concentrate them in a smaller area where they could be more vulnerable to localized outbreaks by $H$. perezi. Conversely, freshwater and sediment diversions also have the potential to reduce salinity, which could hinder the growth and establishment of $H$. perezi.

Another important finding from our study was that blue crab post-larvae that tested positive for DNA of $H$. perezi were found at multiple locations in each of the 4 years of sampling, which suggests that $H$. perezi is endemic to the region rather than occurring episodically. We also detected significant interannual variation in prevalence for settling megalopae at individual locations. This variation could be related to environmental conditions at the site of settlement, differences in exposure to $H$. perezi prior to settlement, or differences in rates of pre-settlement mortality. At present, we can only speculate about where and when megalopae become infected or how the probability of infection might depend on the particular trajectory a larva follows from spawning site to settlement site. These possibilities should be investigated, as infection of offshore larvae could be both a significant source of mortality as well as a mechanism for rapid spread of disease over large areas. The overall prevalence of $H$. perezi detected in blue crab post-larvae $(11.2 \%)$ was just below the range of $12-15 \%$ reported by Hamilton et al. (2011) for unidentified crab larvae from the Clyde Sea. The absence of crabs with detectable $H$. perezi in marshes as documented in this study and others (Messick \& Shields 2000, Pagenkopp Lohan et al. 2013, Rogers et al. 2015a,b) could be explained by a low survival rate for megalopae impacted by $H$. perezi, a lack of transmission in low salinity waters, elimination of the parasite in low salinity habitats or a combination of these mechanisms. More work is needed to assess the importance of $H$. perezi in early life stages of the blue crab.

Our results highlight the importance of considering the environmental tolerances of a pathogen in relation to its host's life history when assessing the pathogen's potential to cause disease. Currently, $~ 80 \%$ of all hard crabs produced in the Gulf of Mexico come from Louisiana. Infection of blue crabs by $H$. perezi in higher salinity waters represents an unaccounted threat to this profitable fishery, especially as it is likely to have a large impact on spawning females. Additional surveys are needed to determine the spatial and temporal extent of the $H$. perezi range in Louisiana, as well estimates of mortality for all affected life stages. A better understanding also is needed of anthropogenic factors that are likely to change the disease ecology of Louisiana blue crabs.

Acknowledgements. This research was made possible in part by grants from The Gulf of Mexico Research Initiative (GRI-013 and GoMRI2012-II-523), Louisiana Department of Wildlife \& Fisheries-S14000, and by a University of Louisiana at Lafayette Doctoral Fellowship to T.J.S. Data are publicly available through the Gulf of Mexico Research Initiative Information \& Data Cooperative (GRIIDC) at https:// data.gulfresearchinitiative.org (doi: R2.x214.000:004). We thank Bree Yednock, Nicholas Keeney, Roxi Di Mauro, Azure Bevington, Joshua Latino, Katherine Ellis and Matilda Elgood Field for assistance with sample collection and Jeffery Shields and Joe Pitula for providing DNA from Hematodinium perezi.

\section{LITERATURE CITED}

Bianchi TS, DiMarco S, Cowan J, Hetland R, Chapman P, Day J, Allison M (2010) The science of hypoxia in the northern Gulf of Mexico: a review. Sci Total Environ 408: $1471-1484$

Boesch DF, Josselyn MN, Mehta AJ, Morris JT, Nuttle WK, Simenstad CA, Swift DJP (1994) Scientific assessment of coastal wetland loss, restoration and management in Louisiana. J Coast Res Spec Issue 20:1-103

Brown S (2015) 2017 coastal master plan modeling: Attachment c3-26 - hydrology and water quality boundary conditions. Version i. Coastal Protection and Restoration Authority, Baton Rouge, LA

Coffey AH, Li C, Shields JD (2012) The effect of salinity on experimental infections of a Hematodinium sp. in blue crabs, Callinectes sapidus. J Parasitol 98:536-542

Condrey R, Gelpi C (2010) Blue crab (Callinectes sapidus) use of the Ship/Trinity/Tiger Shoal Complex as a nationally important spawning/hatching/foraging ground: discovery, evaluation, and sand mining recommendations based on blue crab, shrimp, and spotted seatrout findings. OCS Study MMS 2009-2043. US Dept of the Interior, Minerals Management Service, Gulf of Mexico OCS Region, New Orleans, LA. www.boem.gov/Non-EnergyMinerals/2009-043.aspx

Friedman CS, Crosson LM, Hauser L, Morado JF (2009) North Pacific research board project final report. http:// doc.nprb.org/web/06_prjs/623_FINAL\%20REPORT\% 20 Friedman \%20et\%20al\%20202009\%20FINAL.pdf

Gandy R, Schott EJ, Crowley C, Leone EH (2015) Temperature correlates with annual changes in Hematodinium perezi prevalence in blue crab Callinectes sapidus in Florida, USA. Dis Aquat Org 113:235-243

Gelpi C, Condrey RE, Fleeger JW, Dubois SF (2009) Discovery, evaluation, and implications of blue crab, Cal- 
linectes sapidus, spawning, hatching, and foraging grounds in federal (US) waters offshore of Louisiana. Bull Mar Sci 85:203-222

Gelpi Jr CG, Fry B, Condrey RE, Fleeger JW, Dubois SF (2013) Using $\delta^{13} \mathrm{C}$ and $\delta^{15} \mathrm{~N}$ to determine the migratory history of offshore Louisiana blue crab spawning stocks. Mar Ecol Prog Ser 494:205-218

Hamilton KM, Tew IF, Atkinson R, Roberts EC (2011) Occurrence of the parasite genus Hematodinium (alveolata: Syndinea) in the water column. J Eukaryot Microbiol 58: 446-451

Lee R, Frischer ME (2004) The decline of the blue crab. Am Sci 92:548-553

Messick GA, Shields JD (2000) Epizootiology of the parasitic dinoflagellate Hematodinium sp. in the American blue crab Callinectes sapidus. Dis Aquat Org 43:139-152

Moore LJ, Patsch K, List JH, Williams SJ (2014) The potential for sea-level-rise-induced barrier island loss: insights from the Chandeleur Islands, Louisiana, USA. Mar Geol 355:244-259

Newman MW, Johnson CA (1975) A disease of blue crabs (Callinectes sapidus) caused by a parasitic dinoflagellate, Hematodinium sp. J Parasitol 61:554-557

Pagenkopp Lohan KM, Small HJ, Shields JD, Place AR, Reece KS (2013) Conservation in the first internal transcribed spacer (ITS1) region of Hematodinium perezi (genotype III) from Callinectes sapidus. Dis Aquat Org 103:65-75

Parmenter KJ, Vigueira PA, Morlok CK, Micklewright JA, Smith KM, Paul KS, Childress MJ (2013) Seasonal prevalence of Hematodinium sp. infections of blue crabs in three South Carolina (USA) rivers. Estuar Coasts 36: 174-191

Perry H, VanderKooy S (2015) The blue crab fishery of

Editorial responsibility: Dieter Steinhagen,

Hannover, Germany the Gulf of Mexico, United States: a regional management plan. Publication 243. Gulf States Marine Fisheries Commission, Ocean Springs, MS. www.gsmfc.org/ publications/GSMFC\%20Number\%20243_web.pdf

Rogers HA, Taylor SS, Hawke JP, Anderson Lively JA (2015a) Prevalence and distribution of three protozoan symbionts in blue crab (Callinectes sapidus) populations across Louisiana, USA. Dis Aquat Org 114:1-10

Rogers HA, Taylor SS, Hawke JP, Schott EJ, Anderson Lively JA (2015b) Disease, parasite, and commensal prevalences for blue crab Callinectes sapidus at shedding facilities in Louisiana, USA. Dis Aquat Org 112: 207-217

Sandoz M, Rogers R (1944) The effect of environmental factors on hatching, moulting, and survival of zoea larvae of the blue crab Callinectes sapidus rathbun. Ecology 25: 216-228

Shields J, Overstreet R (2007) Diseases, parasites, and other symbionts. The blue crab Callinectes sapidus. University of Maryland Sea Grant College, College Park, MD, p 299-417

Shields J, Squyars C (2000) Mortality and hematology of blue crabs, Callinectes sapidus, experimentally infected with the parasitic dinoflagellate Hematodinium perezi. Fish Bull 98:139-152

Shields JD, Sullivan SE, Small HJ (2015) Overwintering of the parasitic dinoflagellate Hematodinium perezi in dredged blue crabs (Callinectes sapidus) from Wachapreague Creek, Virginia. J Invertebr Pathol 130:124-132

Stone GW, Pepper DA, Xu J, Zhang X (2004) Ship shoal as a prospective borrow site for Barrier Island restoration, coastal south-central Louisiana, USA: numerical wave modeling and field measurements of hydrodynamics and sediment transport. J Coast Res 20:70-88

Submitted: October 26, 2015; Accepted: April 8, 2016 Proofs received from author(s): May 30, 2016 